\title{
Pituitary Stalk Lesion
}

National Cancer Institute

\section{Source}

National Cancer Institute. Pituitary Stalk Lesion. NCI Thesaurus. Code C121146.

An anomaly in the pituitary stalk that can be developmental, inflammatory, infiltrative, iatrogenic or traumatic. 